\title{
Estimation of the cutoff value of vitamin D: the Dong-gu study
}

Seong-Woo Choi ${ }^{1}$, Sun-Seog Kweon ${ }^{2,3}$, Jin-Su Choi ${ }^{2}$, Jung-Ae Rhee ${ }^{2}$, Young-Hoon Lee ${ }^{4}$, Hae-Sung Nam ${ }^{5}$ Seul-Ki Jeong ${ }^{6}$, Kyeong-Soo Park', So-Yeon Ryu ${ }^{1}$, Hye-Rim Song ${ }^{8}$ and Min-Ho Shin ${ }^{2 *}$

\begin{abstract}
Background: Vitamin D plays an essential role in bone health and growth, but the optimal serum 25-hydroxyvitamin D $(25(\mathrm{OH}) \mathrm{D})$ concentration is not known. This study was performed to investigate the optimal 25(OH)D concentration in regard to parathyroid hormone (PTH) concentration in the Korean general population aged 50 years or older.

Findings: The study population consisted of 8,857 subjects (3,545 men and 5,312 women) who participated in the baseline survey of the Dong-gu study, conducted in Korea between 2007 and 2010. Serum 25(OH)D and PTH concentrations were measured by chemiluminescent microparticle immunoassay. The optimal $25(\mathrm{OH}) \mathrm{D}$ concentration was estimated by using nonlinear regression model. Our data show that PTH concentration reached a theoretical plateau at $38.2 \mathrm{pg} / \mathrm{ml}$ and corresponding 25(OH)D concentration was $21.1 \mathrm{ng} / \mathrm{ml}$ in men and PTH concentration at $42.9 \mathrm{pg} / \mathrm{ml}$ and 25(OH)D concentration at $13.8 \mathrm{ng} / \mathrm{ml}$ in women.
\end{abstract}

Conclusions: These results indicate that, for Korean general population aged 50 years or older, the optimal $25(\mathrm{OH}) \mathrm{D}$ concentration is $21.1 \mathrm{ng} / \mathrm{ml}$ in men and $13.8 \mathrm{ng} / \mathrm{ml}$ in women.

Keywords: Vitamin D, Parathyroid hormone, 25-hydroxyvitamin D, Cutoff value

\section{Background}

Vitamin D deficiency is well known to be a risk factor and an important determinant of osteoporosis [1,2]: $80 \%$ to $90 \%$ of vitamin $\mathrm{D}$ is produced from 7-dehydrocholesterol in the skin after adequate ultraviolet exposure. Only $10 \%$ to $20 \%$ of vitamin $\mathrm{D}$ is derived from dietary sources such as oily fish, milk, butter, eggs, and supplements [3]. Vitamin D maintains circulating calcium levels by regulating ionized calcium absorption in the bone and intestine, and it indirectly affects the concentrations of parathyroid hormone (PTH) [4].

PTH is a regulator of calcium and phosphate homeostasis [5]. Its secretion increases in response to decreased plasma concentrations of calcium, and it acts to elevate circulating calcium levels by promoting the synthesis of active vitamin $\mathrm{D}(1,25(\mathrm{OH}) \mathrm{D})$ in the kidney. Additionally, PTH stimulates both calcium release from bone and intestinal calcium absorption and increases the reabsorption of active renal calcium [6].

\footnotetext{
* Correspondence: mhshinx@paran.com

${ }^{2}$ Department of Preventive Medicine, Chonnam National University Medical School, 160 Baekseo-ro, Dong-gu, Gwangju 501-746, Republic of Korea Full list of author information is available at the end of the article
}

Based on the hypothesis of hypovitaminosis D and secondary hyperparathyroidism, many researchers have investigated the relationship between vitamin D and PTH to find the optimal vitamin D concentration. However, the results were inconsistent [7-12]. Moreover, evidence from the Korean population is limited [13]. The aim of this study was to investigate the optimal 25-hydroxyvitamin D $(25(\mathrm{OH}) \mathrm{D})$ concentration in regard to PTH concentration in 50 years or older urban Koreans.

\section{Methods}

Subjects

The Dong-gu study is an ongoing prospective populationbased study that was designed to investigate the prevalence, incidence, and risk of factors for chronic disease in an urban elderly population [14]. It enrolled 9,260 subjects (3,711 men and 5,549 women) aged 50 years or older between April and July in 2007 to 2010 in the Dong-gu district of Gwangju Metropolitan City in Korea $\left(35^{\circ} \mathrm{N}\right)$. After exclusion of 347 participants who had incomplete data and 56 participants with estimated glomerular filtration rate (eGFR) values of $<30 \mathrm{ml} / \mathrm{min} / 1.73 \mathrm{~m}^{2}$, a total of $8,857 \mathrm{sub}-$ jects (3,545 men and 5,312 women) were included in the 
present analyses. All participants provided informed consent, and the study was conducted in accordance with the guidelines in the Declaration of Helsinki. The study was approved by the Institutional Review Board of Chonnam National University Hospital (IRB no. I-2008-05-056).

\section{Measurements}

Trained examiners interviewed patients using a standardized questionnaire that assessed cigarette use, alcohol consumption, physical activity, and menopausal status. Blood was drawn from an antecubital vein after a 12-h overnight fast. Serum was separated within $30 \mathrm{~min}$ and stored at $-70^{\circ} \mathrm{C}$ until analysis. All samples were measured using an automated analyzer (model 7600 chemical analyzer, Hitachi Ltd., Tokyo, Japan). The concentrations of serum $25(\mathrm{OH}) \mathrm{D}$ and PTH were measured using an ARCHITECT i2000 chemiluminescent microparticle immunoassay analyzer (Abbott Diagnostics, Abbott Park, IL, USA). The coefficient of variation for the total analytic precision of the assay was $\leq 10 \%$ for $25(\mathrm{OH}) \mathrm{D}$ and $\leq 9 \%$ for PTH. The lower detection limit of the assay was $3.0 \mathrm{ng} / \mathrm{ml}$ for $25(\mathrm{OH}) \mathrm{D}$ and $1.0 \mathrm{pg} / \mathrm{ml}$ for PTH.

\section{Statistical analysis}

Data are presented as the mean \pm standard deviation (SD), or as percentages for categorical variables Vitamin D deficiency was defined as $25(\mathrm{OH}) \mathrm{D}$ concentration $<20 \mathrm{ng} / \mathrm{ml}$. The statistical analysis was conducted using SPSS 18.0 (SPSS, Chicago, IL, USA). The scatterplot and nonlinear regression analysis were used to examine the association between the serum PTH and 25(OH)D concentrations for possible thresholds.

\section{Results and discussion}

The mean age of the subjects was $65.1 \pm 8.1$ years, and $60.0 \%$ were female. The mean $25(\mathrm{OH}) \mathrm{D}$ concentration was $19.2 \pm 5.9 \mathrm{ng} / \mathrm{ml}$ for males and $15.0 \pm 5.1 \mathrm{ng} / \mathrm{ml}$ for females $(P<0.001)$. The mean PTH concentration was $40.6 \pm 17.7 \mathrm{pg} / \mathrm{ml}$ for males and $44.0 \pm 19.4 \mathrm{pg} / \mathrm{ml}$ for females $(P<0.001)$. Male subjects were more likely to be older, have a lower body mass index (BMI), smoke, drink alcohol, and be physically active. The prevalence of vitamin D deficiency $(<20 \mathrm{ng} / \mathrm{ml})$ was $59.8 \%$ in men and $86.2 \%$ in women (Table 1 ).

The relationship between serum 25(OH)D and PTH concentrations was studied using the nonlinear regression model $[9,15]$ :

$$
\mathrm{PTH}(\mathrm{pg} / \mathrm{ml})=\mathrm{a}+b \times \exp (c \times 25[\mathrm{OH}] \mathrm{D}[\mathrm{ng} / \mathrm{ml}]) .
$$

Our resulting equations were as follows:

$$
\begin{aligned}
\operatorname{PTH}(\mathrm{pg} / \mathrm{ml}) & =34.94+65.24 \\
& \times \exp (-0.142 \times 25[\mathrm{OH}] \mathrm{D}[\mathrm{ng} / \mathrm{ml}])(\text { Male }) \\
\operatorname{PTH}(\mathrm{pg} / \mathrm{ml}) & =38.82+86.81 \\
& \times \exp (-0.215 \times 25[\mathrm{OH}] \mathrm{D}[\mathrm{ng} / \mathrm{ml}])(\text { Female })
\end{aligned}
$$

\begin{tabular}{|c|c|c|c|c|}
\hline & Male & Female & Total & $P$ values \\
\hline$N(\%)$ & $3,545(40.0)$ & $5,312(60.0)$ & $8,857(100.0)$ & - \\
\hline Age (years) & $66.1 \pm 8.0$ & $64.4 \pm 8.2$ & $65.1 \pm 8.1$ & $<0.001$ \\
\hline BMI $\left(\mathrm{kg} / \mathrm{m}^{2}\right)$ & $23.9 \pm 2.8$ & $24.6 \pm 3.0$ & $24.3 \pm 2.9$ & $<0.001$ \\
\hline Month of blood collection & & & & 0.004 \\
\hline April & $762(21.5)$ & $1,010(19.0)$ & $1,772(20.0)$ & \\
\hline May & $1,132(31.9)$ & $1,749(32.9)$ & $2,881(32.5)$ & \\
\hline June & $1,079(30.4)$ & $1,580(29.7)$ & $2,659(30.0)$ & \\
\hline July & $572(16.1)$ & $973(18.3)$ & $1,545(17.4)$ & \\
\hline Smoking (\%) & $865(24.4)$ & $99(1.9)$ & $964(10.9)$ & $<0.001$ \\
\hline Alcohol intake (\%) & $2,416(68.2)$ & $1,690(31.8)$ & $4,106(46.4)$ & $<0.001$ \\
\hline Physically active ${ }^{a}(\%)$ & $920(26.8)$ & $667(13.0)$ & $1,587(18.5)$ & $<0.001$ \\
\hline PTH (pg/ml) & $40.6 \pm 17.7$ & $44.0 \pm 19.4$ & $42.7 \pm 18.8$ & $<0.001$ \\
\hline 25(OH)D (ng/ml) & $19.2 \pm 5.9$ & $15.0 \pm 5.1$ & $16.7 \pm 5.8$ & $<0.001$ \\
\hline Vitamin D deficient $^{\mathrm{b}}(\%)$ & $2,120(59.8)$ & 4,595 (86.5) & $6,715(75.8)$ & $<0.001$ \\
\hline Postmenopause (\%) & & $5,081(96.2)$ & & \\
\hline
\end{tabular}

With this approach, the PTH concentration reached a theoretical plateau at $38.2 \mathrm{pg} / \mathrm{ml}$ and the corresponding $25(\mathrm{OH}) \mathrm{D}$ concentration was $21.1 \mathrm{ng} / \mathrm{ml}$ in men (Figure 1 )

\section{Table 1 Baseline characteristics of subjects}

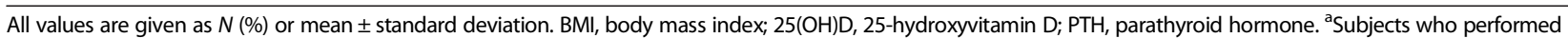
$30 \mathrm{~min}$ or more of moderate activity at least 5 days a week or 20 min of vigorous physical activity at least 3 days a week were regarded as doing physical activity; $\mathrm{b}_{25}(\mathrm{OH}) \mathrm{D}<20 \mathrm{ng} / \mathrm{ml}$. 


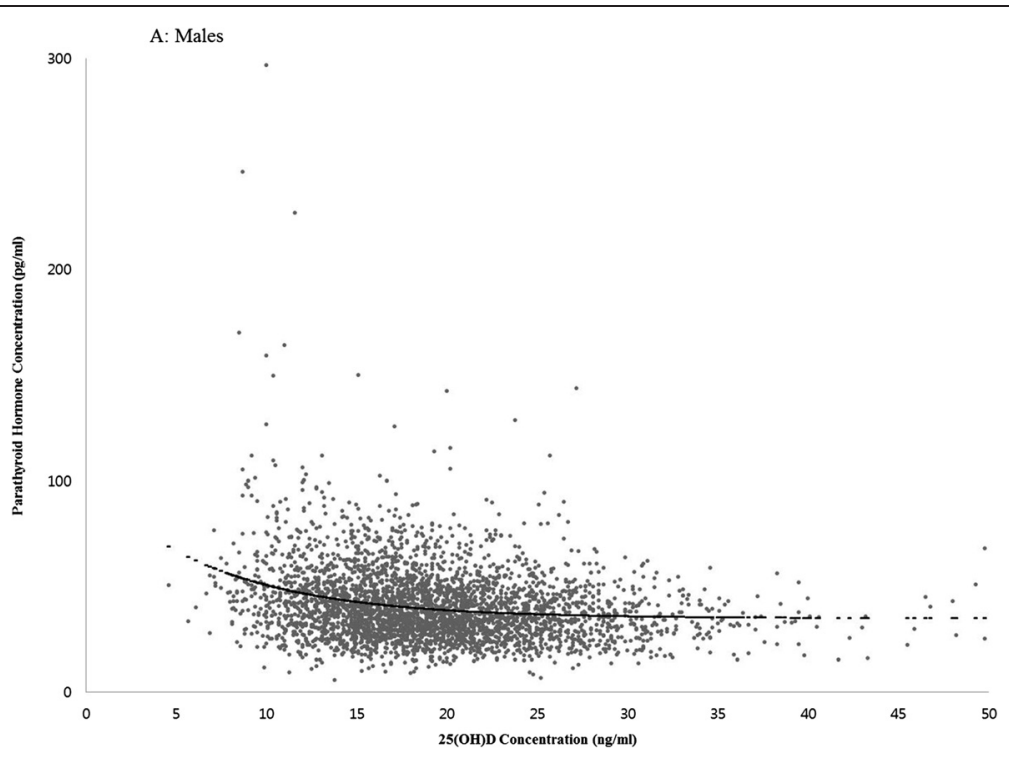

Figure 1 25(OH)D concentration versus parathyroid hormone concentration (males).

and the PTH concentration at $42.9 \mathrm{pg} / \mathrm{ml}$ and the $25(\mathrm{OH})$ $\mathrm{D}$ concentration at $13.8 \mathrm{ng} / \mathrm{ml}$ in women (Figure 2).

The optimal 25(OH)D concentration, the threshold value for 25(OH)D at which PTH plateaus, has been suggested based on the inverse relation between 25(OH)D and PTH [16]. Because PTH is negatively associated with greater bone loss, maintaining a sufficient concentration of $25(\mathrm{OH}) \mathrm{D}$ is believed to have a protective effect on bone health [16]. However, there is a lack of consensus as to what constitutes an optimal $25(\mathrm{OH}) \mathrm{D}$ concentration. Some researchers reported that an optimal threshold value was not found [17], while others reported a wide range of estimates: 8 to $44 \mathrm{ng} / \mathrm{ml}$ [7-12], with most clustered at 30 to $44 \mathrm{ng} / \mathrm{ml}$ [9-12]. In the present study, PTH reached a plateau at a 25(OH)D concentration of 30 to $40 \mathrm{ng} / \mathrm{ml}$ in males, but did not reach a plateau in females. It is possible that ethnic differences may have influenced the relationship between $25(\mathrm{OH}) \mathrm{D}$ concentrations and PTH. In the NHANES study [18], the optimal concentration was $20 \mathrm{ng} / \mathrm{ml}$ in Black Americans but was not found in White or Mexican Americans.

Our data demonstrate the optimal concentration was different according to gender. 25(OH)D is well known to be affected by gender differences. Men tend to spend a

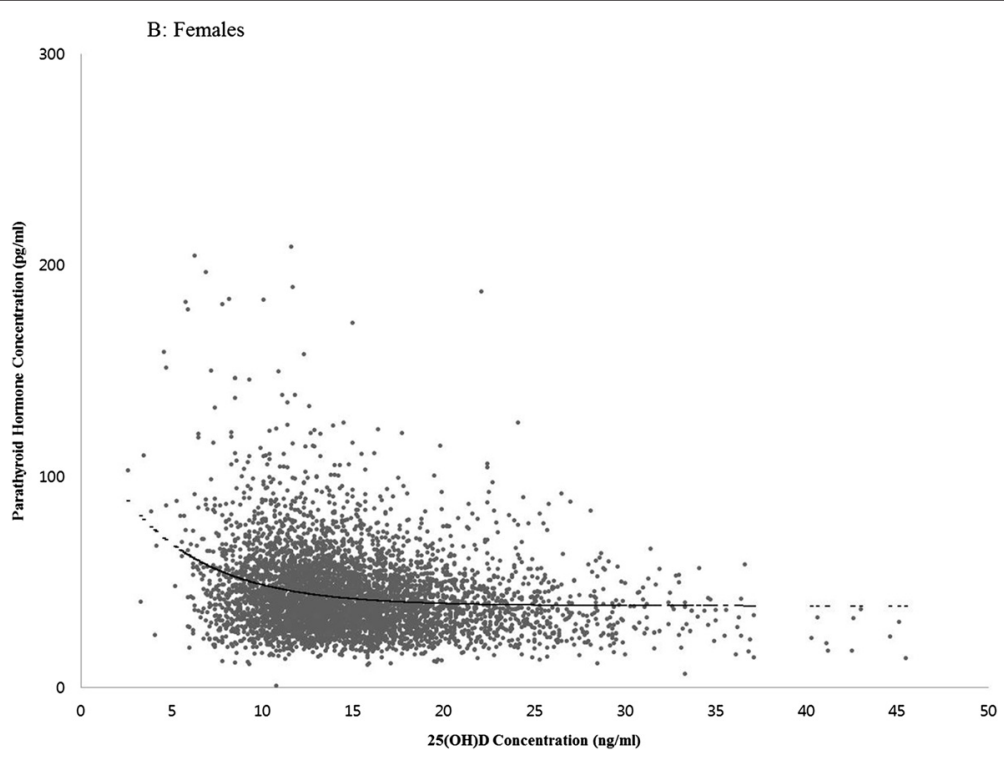

Figure 2 25(OH)D concentration versus parathyroid hormone concentration (females). 
greater amount of time outdoors than women [19], and the difference in sun exposure may play a role in genderspecific $25(\mathrm{OH}) \mathrm{D}$ concentrations. $25(\mathrm{OH}) \mathrm{D}$-binding protein (DBP) may also contribute to gender differences in 25 $(\mathrm{OH}) \mathrm{D}$ status [20], as DBP levels are significantly higher in women than in men and are positively correlated with overall 25(OH)D concentrations [20].

The ongoing difficulties and controversies associated with the relationship between PTH and 25(OH)D imply that this approach is not the best one to identify vitamin D sufficiency in populations. New approaches to this problem, potentially beyond the hypovitaminosis $\mathrm{D}$, secondary hyperparathyroidism pathway, should be pursued [16].

The main strengths of this study lie in its populationbased design and use of a relatively large sample size, which minimized selection bias and provided sufficient statistical power. However, a number of limitations should also be considered. First, the study used a crosssectional design. Second, it had a comparatively limited ability to explain seasonal changes in $25(\mathrm{OH}) \mathrm{D}$, partly due to a lack of information on sun exposure during the four seasons because the samples were collected April to June during 2007 to 2010. Finally, we performed only a single measurement of the serum 25(OH)D concentrations; therefore, the data reflect only a single point in time rather than long-term exposure.

\section{Conclusion}

We estimated the optimal $25(\mathrm{OH}) \mathrm{D}$ concentration in the Korean general population aged 50 years or older. The optimal $25(\mathrm{OH}) \mathrm{D}$ concentration is $21.1 \mathrm{ng} / \mathrm{ml}$ at $38.2 \mathrm{pg} / \mathrm{ml} \mathrm{PTH}$ concentration in men and $13.8 \mathrm{ng} / \mathrm{ml}$ 25(OH)D concentration at $42.9 \mathrm{pg} / \mathrm{ml}$ PTH concentration in women.

\section{Abbreviations}

25(OH)D: 25-hydroxyvitamin D; BMl: body mass index; eGFR: estimated glomerular filtration rate; LOWESS: locally weighted estimated scatterplot smoothing; PTH: parathyroid hormone.

\section{Competing interests}

The authors declare that they have no competing interests.

\begin{abstract}
Authors' contributions
SWC and MHS contributed to the study design, data acquisition, statistical analysis, interpretation of the results, and manuscript preparation. YHL, HSN, SKJ, KSP, and SYR were involved with the data acquisition and statistical analysis. JSC and JAR conceived and designed the study. SSK participated in the design of the study and carried out the interpretation of data. HRS had an important role in the research and data acquisition. All authors contributed to the preparation and are responsible for the final editing and approval of the manuscript.
\end{abstract}

\section{Acknowledgment}

This study was supported by a research fund from Chosun University, 2014.

\section{Author details}

'Department of Preventive Medicine, Chosun University Medical School, 309, Pilmun-daero, Dong-gu, Gwangju 501-759, Republic of Korea. ${ }^{2}$ Department of Preventive Medicine, Chonnam National University Medical School, 160 Baekseo-ro, Dong-gu, Gwangju 501-746, Republic of Korea. ${ }^{3}$ Jeonnam Regional Cancer Center, Chonnam National University Hwasun Hospital, 322 Seoyang-ro, Hwasun, Jeollanamdo 519-809, Republic of Korea. ${ }^{4}$ Department of Preventive Medicine \& Institute of Wonkwang Medical Science, Wonkwang University School of Medicine, 344-2 Shinyong-dong, Iksan, Jeollabukdo 570-711, Republic of Korea. ${ }^{5}$ Department of Preventive Medicine, Chungnam National University Medical School, Munhwa 1(il)-dong," Jung-gu, Daejeon 301-747, Republic of Korea. ${ }^{6}$ Department of Neurology \& Research Institute of Clinical Medicine, Biomedical Institute of Chonbuk National University Hospital, Chonbuk National University, San 2-20, Geumam-dong, Deokjin-gu, Jeonju, Jeollabukdo 561-180, Republic of Korea. ${ }^{7}$ Department of Preventive Medicine, Seonam University College of Medicine, 439, Chunhyang-ro, Namwon, Jeollabukdo 590-711, Republic of Korea. ${ }^{8}$ Department of Laboratory Medicine, Chonnam National University Hwasun Hospital, 322 Seoyang-ro, Hwasun, Jeollanamdo 519-809, Republic of Korea.

Received: 18 August 2014 Accepted: 13 February 2015

Published online: 12 March 2015

\section{References}

1. Lips P. Vitamin D, deficiency and secondary hyperparathyroidism in the elderly: consequences for bone loss and fractures and therapeutic implications. Endocr Rev. 2001;22:477-501.

2. Holick MF. McCollum Award Lecture, 1994: vitamin D - new horizons for the 21st century. Am J Clin Nutr. 1994;60:619-30.

3. Holick MF. Evolution, biologic functions, and recommended dietary allowances for vitamin D. In: Holick MF, editor. Vitamin D: physiology, molecular biology and clinical applications. Totowa, New Jersey: Humana Press; 1999. p. 1-16.

4. Holick MF. Resurrection of vitamin D deficiency and rickets. J Clin Invest. 2006;116:2062-72.

5. Holick MF. Vitamin D, and bone health. J Nutr. 1996;126:S1159-64.

6. Tomaschitz A, Ritz E, Pieske B, Fahrleitner-Pammer A, Kienreich K, Horina JH, et al. Aldosterone and parathyroid hormone: a precarious couple for cardiovascular disease. Cardiovasc Res. 2012;94:10-9.

7. Lips P, Wiersinga A, van Ginkel FC, Jongen MJ, Netelenbos JC, Hackeng WH, et al. The effect of vitamin D supplementation on vitamin D status and parathyroid function in elderly subjects. J Clin Endocrinol Metab. 1988;67:644-50.

8. Malabanan A, Veronikis IE, Holick MF. Redefining vitamin D insufficiency. Lancet. 1998;351:805-6.

9. Chapuy MC, Preziosi P, Maamer M, Arnaud S, Galan P, Hercberg S, et al. Prevalence of vitamin $D$ insufficiency in an adult normal population. Osteoporos Int. 1997;7:439-43.

10. Peacock M. Effects of calcium and vitamin D insufficiency on the skeleton. Osteoporos Int. 1998:8:S45-51.

11. Dawson-Hughes B, Harris SS, Dallal GE. Plasma calcidiol, season, and serum parathyroid hormone concentrations in healthy elderly men and women. Am J Clin Nutr. 1997;65:67-71.

12. Krall EA, Sahyoun N, Tannenbaum S, Dallal GE, Dawson-Hughes B. Effect of vitamin $D$ intake on seasonal variations in parathyroid hormone secretion in postmenopausal women. N Engl J Med. 1989;321:1777-83.

13. Kim G, Oh KW, Jang EH, Kim MK, Lim DJ, Kwon HS, et al. Relationship between vitamin $\mathrm{D}$, parathyroid hormone, and bone mineral density in elderly Koreans. J Korean Med Sci. 2012;27:636-43.

14. Kweon SS, Shin MH, Jeong SK, Nam HS, Lee YH, Park KS, et al. Cohort profile: the Namwon study and the Dong-gu study. Int J Epidemiol. 2013:43:558-67.

15. Guillemant J, Taupin P, Le HT, Taright N, Allemandou A, Pérès G, et al. Vitamin $\mathrm{D}$ status during puberty in French healthy male adolescents. Osteoporos Int. 1999;10:222-5.

16. Willett AM. Vitamin D, status and its relationship with parathyroid hormone and bone mineral status in older adolescents. Proc Nutr Soc. 2005;64:193-203.

17. Vieth R, Ladak Y, Walfish PG. Age-related changes in the 25-hydroxyvitamin $D$ versus parathyroid hormone relationship suggest a different reason why older adults require more vitamin D. J Clin Endocrinol Metab. 2003:88:185-91.

18. Gutiérrez OM, Farwell WR, Kermah D, Taylor EN. Racial differences in the relationship between vitamin $\mathrm{D}$, bone mineral density, and parathyroid 
hormone in the National Health and Nutrition Examination Survey. Osteoporos Int. 2011;22:1745-53.

19. Carnevale V, Modoni S, Pileri M, Di Giorgio A, Chiodini I, Minisola S, et al. Longitudinal evaluation of vitamin $D$ status in healthy subjects from southern Italy: seasonal and gender differences. Osteoporos Int. 2001;12:1026-30.

20. Bolland MJ, Grey AB, Ames RW, Horne AM, Mason BH, Wattie DJ, et al. Age-, gender-, and weight-related effects on levels of 25-hydroxyvitamin $D$ are not mediated by vitamin D binding protein. Clin Endocrinol. 2007;67:259-64.

Submit your next manuscript to BioMed Central and take full advantage of:

- Convenient online submission

- Thorough peer review

- No space constraints or color figure charges

- Immediate publication on acceptance

- Inclusion in PubMed, CAS, Scopus and Google Scholar

- Research which is freely available for redistribution 